\title{
LYHYTPÄIVÄKRYSANTEEMIN PISTOKASMONISTUS- JA TAIMIKASVATUSKOKEISTA
}

\author{
Helsingin Yliopiston puutarhatieteen laitos
}

ERKKI KaUKOVIRTA

Saapunut 21. 11. 1962

Nykyään tiedetään, että krysanteemi voidaan saada kukkimaan minä vuoden aikana tahansa, jos vain päivänpituus ja valoisuusolosuhteet järjestetään sen vaatimusten mukaisiksi. Kaupallisessa viljelyssä tätä mahdollisuutta käytetään yleisesti hyväksi ympärivuotisessa krysanteemin tuotannossa. Tämän viljelytavan avulla ei pyritä ainoastaan jatkuvaan kukkatuotantoon, vaan samalla viljelyaika, lisäyksestä kukintaan, halutaan saada mahdollisimman lyhyeksi. Se edellyttää kuitenkin, että viljely suoritetaan kaikissa vaiheissaan tarkoituksenmukaisesti ja oikein. Tässä mielessä viljelymenetelmien kehittämiseksi on jo kauan suoritettu tutkimustyötä varsinkin Yhdysvalloissa ja monissa Länsi-Euroopan maissa.

Seuraavassa on tarkoitus selostaa eräitä niistä lyhytpäiväkrysanteemin viljelykokeista, jotka Helsingin Yliopiston puutarhatieteen laitoksen toimesta on järjestetty. Lähinnä tässä tarkastellaan taimikasvatusta, pistokkaiden juurruttamista ja pistokastaimien koulimisen vaikutusta sadon laatuun.

\section{Pistokkaiden juurruttaminen}

Varsin yleisesti on viljelijäin keskuudessa vallalla käsitys, että krysanteemin pistokkaat on helppo juurruttaa, kuten yleensä ruohomaiset pistokkaat. Siitä huolimatta korkealaatuisten pistokkaiden tuottaminen vaatii erityistä huolellisuutta Viime aikoina on käynyt ilmi, että lyhytpäiväviljelyyn kannattaa istuttaa ainoastaan ensiluokkaisia pistokastaimia (mm. 13, 18). Post (13) on havainnut krysanteemin pistokkaiden puutuvan nopeasti, jos juurrutusolosuhteet eivät ole oikein valitut tai pistokkaiden hoito on virheellistä. Puutuminen aiheuttaa kasvun pysähtymisen, josta edelleen Postin havaintojen mukaan voi olla seurauksena jopa 2 -3 viikon viivästyminen taimien kehityksessä. Juurtumisen onnistuminen riippuu monista tekijöistä kuten lämpötilasta, pistokasmateriaalista, kosteussuhteista ja alustamateriaalista. Juurrutusalustan valinnan avulla voidaan vaikuttaa myös kosteussuhteisiin varsin helposti kuten Post (13) toteaa. 


\section{Juurrutusalustat}

Pistokkaiden juurruttamiseen käytetään laadultaan erilaisia alustoja, joista yleisimpiä ovat hiekka, multa, turve ja vermikuliitti. Mainituilla juurrustusalustoilla on suoritettu lukuisia tutkimuksia, joissa niiden ominaisuuksista on ilmennyt mm. seuraavaa.

Hiekka on osoittautunut juurien kehittymisen kannalta edulliseksi, mutta sitä käytettäessä on pistokkaiden puutumisen vaara ilmeinen $(7,11,19)$. — Mullan käyttöä puolletaan varsinkin krysanteemien pistokkaiden juurrutuksessa lähinnä siksi, että sen sisältämät ravinteet estävät kasvun pysähtymisen ja puutumisen juurrutuksen aikana $(19,20)$. - Turpeen etuina pitää STOUTEMYER (19) sen hyvää kosteuden pidätyskykyä ja sen sisältämiä juurtumista kiihoittavia orgaanisia yhdisteitä. - Vermikuliitista saadut tulokset ovat yleensä olleet positiivisia ja Hudson (8) pitää sen keksimistä yhtenä suurimmista edistysaskeleista mitä pistokkaiden juurruttamisen hyväksi on tehty. - Juurrutusalustaa valittaessa pitää Post (13) tärkeimpänä kosteussuhteiden huomioon ottamista, sillä hän on tutkimuksissaan havainnut juurrutuksen epäonnistumisen aiheutuvan useimmissa tapauksissa riittämättömästä veden saannista.

\section{Hormonivalmisteiden käyttö}

Krysanteemin kaupallisessa lisäyksessä käytetään nykyään yleisesti juurrutushormoneja. Käytön katsotaan olevan edullista, sillä hormonivalmisteet varmentavat juurtumisen. Sen sijaan niiden ei ole todettu nopeuttavan juurtumista (mm. 2, 9). RupPrEcht (17) ja RiEHL (16) ovat todenneet krysanteemin pistokkaiden hormonikäsittelystä koituvan sitä suuremman edun mitä korkeampi lämpötila ja valovoimakkuus ja mitä pienempi kosteusprosentti alustassa on. Lisäksi RIEHL (16) havaitsi, että liian märässä alustassa hormonikäsittely voi olla jopa haitallista.

\section{Juurtuneiden pistokkaiden koulinta}

Pistokastaimien koulimisen vaikutuksesta krysanteemien sadon laatuun ei ilmeisesti olla vielä täysin selvillä. Työnsäästön aikaansaamiseksi on tapana luopua kokonaan koulimisesta ja istuttaa juurtuneet pistokkaat suoraan kasvupaikalleen. Monissa tutkimuksissa (mm. 10, 13) on saatu kasvupaikalleen suoraan istutetuista krysanteemeistä tyydyttävää, usein yhtä hyvää satoa kuin koulituista taimista. Eräät toiset mm. Allerton (1) ja Bull (3) suosittelevat koulimatta istuttamista ensisijaisesti silloin, kun taimet kasvatetaan yksivartisina. Bull (3) on havainnut sadon laadun heikkenevän, jos koulimaton taimi kasvatetaan useampi kuin yksivartisena. Hän selittää sen johtuvan siitä, ettei juuristo ehdi kehittyä kasvupaikalle suoraan istutettaessa riittävän voimakkaaksi.

Taimikasvatukseen liittyy läheisesti kysymys siitä kuinka kauan taimien on saatava kehittyä ennen kuin lyhytpäiväkäsittely aloitetaan. SEARlen ja Machinin (18) selostamissa kokeissa eri lajikkeiden havaittiin tarvitsevan tietyn pituisen 
kasvuajan ennen pimentämisen aloittamista, ja todettiin sen vaihtelevan lajikkeesta riippuen 6:sta 20 vrk:een. CATHEY (4) ei puolestaan havainnut Ancore, Golden Chort ja Snow lajikkeilla kokeillessaan mitään eroja kehityksessä vaikka kasvuaika ennen pimentämistä vaihteli 0:sta 6 viikkoon. Sen sijaan Herrmans (7) pitää kolmen viikon kasvuaikaa ennen pimentämistä kaikille lajikkeille riittävänä. ОKADA (12) määrittelee tämän ajan verson pituuden perusteella ja katsoo, että versojen tulee olla vähintään $18-24 \mathrm{~cm}: n$ pituisia lyhytpäiväkäsittelyä aloitettaessa.

\section{Krysanteemin pistokkaiden juurruttamiskoe}

Krysanteemin pistokkaiden juurrutuskoe suoritettiin Hyvinkäällä K. Vakkurin kauppapuutarhassa elokuussa v. 1960. Juurrutushuoneen keskilämpö oli kokeen suorittamisen aikana $17^{\circ} \mathrm{C}$ ja se vaihteli $15^{\circ} \mathrm{C}$ :stä $25^{\circ} \mathrm{C}$ :een.

Kokeessa juurrutettiin kolmen krysanteemilajikkeen (Silvertone, Halo, Indianapolis) pistokkaita viidellä erilaisella alustalla, jotka olivat:

1. Hiekka-alusta

2. Multa-alusta

3. Vermikuliittialusta

4. Uusi turvehiekka-alusta

5. Vanha turvehiekka-alusta

Alustan vahvuus oli $6 \mathrm{~cm}$, josta hiekka-alustan alla oli $\mathrm{n} .2 \mathrm{~cm}$ turvetta kosteuden tasaamiseksi alustassa. Multa ja turvehiekka-alustojen pinnalla oli $\mathrm{n} .1 \mathrm{~cm}$ hiekkaa kasteluvahinkojen estämiseksi. Turvehiekka sisälsi 1:1 turvetta ja hiekkaa tasaisesti sekoitettuna.

Hiekka, jota käytettiin, oli syvältä harjun sisältä nostettua. Se oli aikaisemmassa käytössä todettu puhtaaksi ja erittäin hyvin juurrutushiekaksi soveltuvaksi. Raekoko oli 1-2 mm. Multana käytettiin kauppapuutarhan istutusmultaa, joka oli kalkittu edellisenä syksynä pellossa ja siihen oli lisätty samalla kynnön yhteydessä turvepehkua. Vermikuliittina käytettiin Suomen Mineraali Oy:n tuottamaa kauppavalmistetta. Turve oli maatumisasteeltaan alhaista sararahkaturvetta, jonka $\mathrm{pH}$ oli 4.7.

Pistokkaat olivat ns. latvapistokkaita, ja ne kerättiin kauppapuutarhan omista lisäystaimista. Lisäystaimet oli istutettu toukokuussa Frampton Nurseries Ltd:n toimittamista pistokkaista. Kerätyt versot leikattiin n. $3.5 \mathrm{~cm}: n$ mittaisiksi pistokkaiksi, jotka jaettiin kahteen osaan, joista toinen käsiteltiin Rootone 9 juurrutushormonilla. Toinen erä laitettiin juurtumaan käsittelemättömänä. Pistokkaiden väliset etäisyydet olivat $5 \times 5 \mathrm{~cm}$.

Päivisin pistokkaat peitettiin muovikalvolla, joka pingoitettiin $10 \mathrm{~cm}$ korkeudelle niiden yläpuolelle. Tarvittaessa suoritettiin suihkutus kastelukannua apuna käyttäen. Muutoin pistokkaiden hoito juurrutusaikana tapahtui tavanomaisten hoito-ohjeiden mukaisesti.

Koe järjestettiin Split plots (FINNEy 5)-kaaviota soveltaen. Alustojen muodostama pääruutu jaettiin käsittelytapojen mukaan osaruutuihin. Kerranteita oli 
kokeessa kolme, kussakin 21 pistokasta. Koetulosten tilastomatemaattinen käsittely suoritettiin Gouldenin (6) ja Mattilan (11) esittämien kaavojen mukaan.

Pistokkaiden juurtumista arvosteltaessa otettiin huomioon seuraavat seikat:

1. Juurtumisaika. Koejäsenessä katsottiin juurtuminen tapahtuneeksi silloin, kun $75 \%$ pistokkaista oli juurtunut alustaan kiinni.

2. Juurtumisprosentti, joka laskettiin koetta lopetettaessa.

3. Juurten lukumäärä pistokkaassa. Laskettaessa otettiin huomioon vain pistokkaasta lähtevät juuret, eikä juuren haaroja.

4. Juuriston pituus mitattuna pistokkaan tyvestä juuriston uloimpaan kärkeen.

5. Pistokkaan verson lisäkavu juurrutuksen aikana, joka laskettiin koetta lopetettaessa mitatun keskimääräisen versonpituuden ja pistämishetkellä mitatun versonpituuden erotuksena.

Koetta lopetettaessa kiintyi huomio eri alustoilla juurtuneiden pistokkaiden juuriston erilaiseen muotoon. Turpeen ja hiekan seosalustalla juuristo oli samantyyppinen kuin multa-alustalla. Muilla alustoilla juuriston muoto oli selvästi erilainen. Kuvassa 1 on esitetty kolme luonteenomaisinta juuristotyyppiä.

Kuva 1. Krysanteemin pistokastaimien juurrutuskoe. Hyvinkää v. 1962.

Fig 1. Rooting experiment of chrysanthemum cuttings.
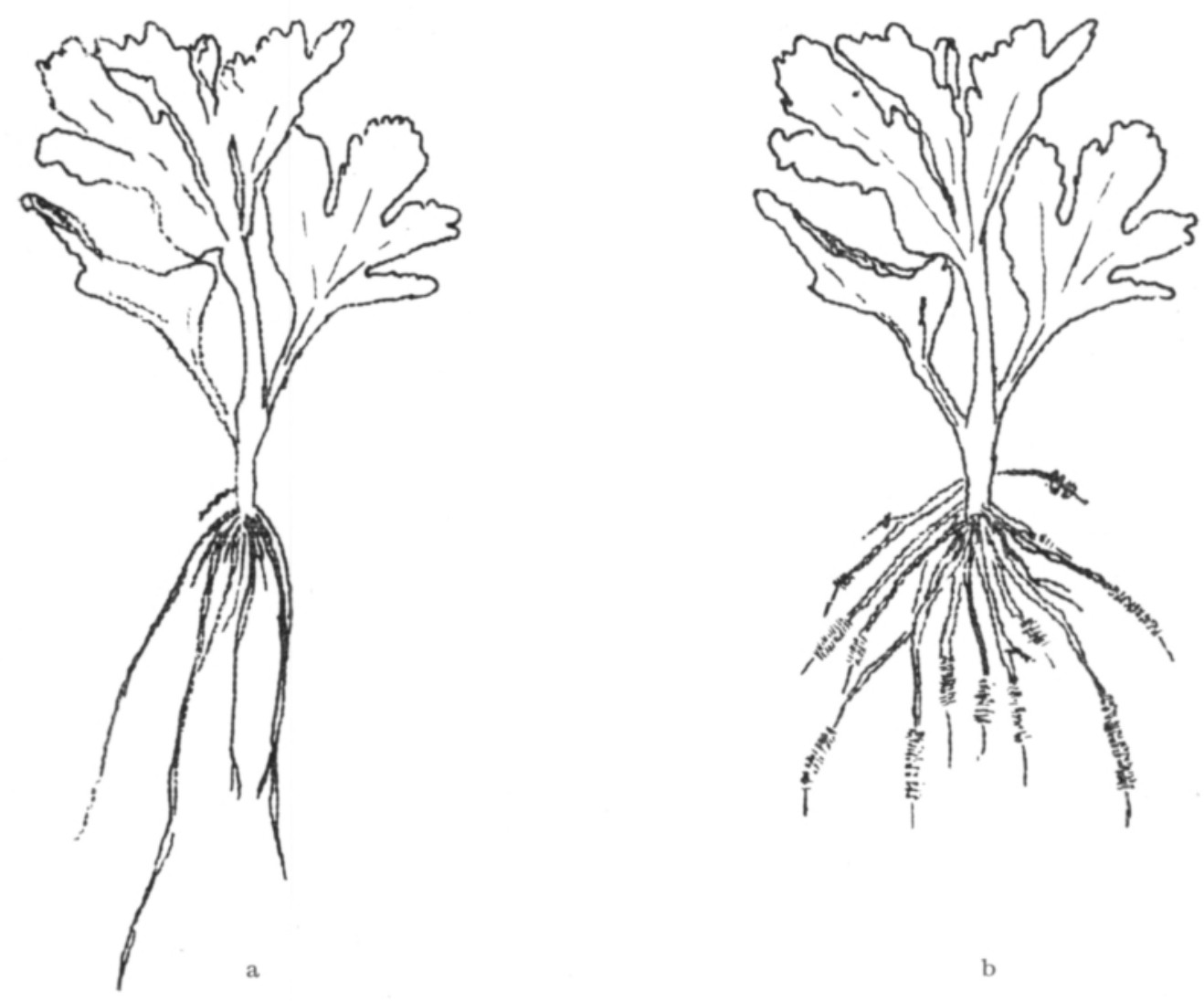


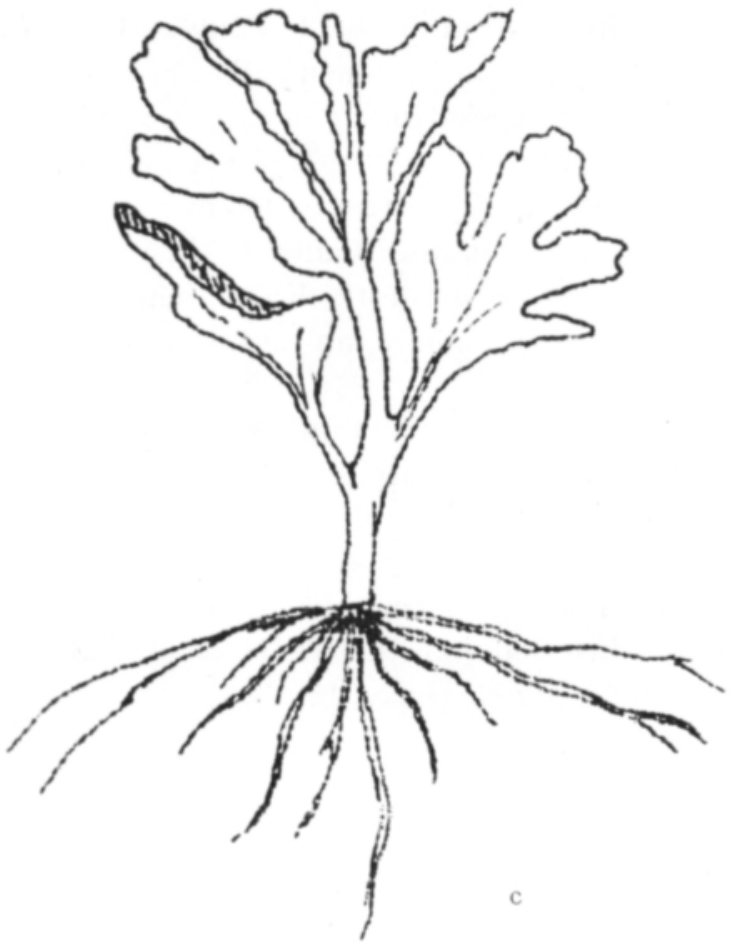

a. Multa-alustalla juurtunut krysanteemin pistokas.

Chrysanthemum cutting rooted in soil.

b. Vermikuliittialustalla juurtunut krysanteemin pistokas.

Chrysanthemum .cutting rooted in vermiculite.

c. Hiekka-alustalla juurtunut krysanteemin pistokas.

Chrysanthemum cutting rooted in sand.

Taulukko 1. Krysanteemin pistokkaiden juurrutuskoe. Hyvinkää v. 1960.

Table 1. Rooting experiment of chrysanthemum cuttings.

\begin{tabular}{|c|c|c|c|c|c|c|c|c|c|c|}
\hline & \multicolumn{4}{|c|}{$\begin{array}{l}\qquad \mathrm{A}=\text { hiekka sand } \\
\mathrm{B}=\text { multa soil } \\
\text { Juurtumisaika, vrk } \\
\text { Time of rooting, days }\end{array}$} & & \multicolumn{5}{|c|}{$\begin{array}{l}\mathrm{C}=\text { vermikuliitti vermiculite } \\
\mathrm{D}=\text { turvehiekka peat }+ \text { sand }\end{array}$} \\
\hline & \multicolumn{5}{|c|}{ Käsittelemättömät } & \multicolumn{5}{|c|}{ Rootone 9:1lä käsitellyt } \\
\hline & \multicolumn{5}{|c|}{ Untreated } & \multicolumn{5}{|c|}{ Treated with Rootone 9} \\
\hline & \multicolumn{4}{|c|}{ Alustat } & & \multicolumn{5}{|c|}{ Alustat } \\
\hline Lajike & \multicolumn{5}{|c|}{ Rooting media } & \multicolumn{5}{|c|}{ Rooting media } \\
\hline Variety & A & B & $\mathrm{C}$ & D & \multicolumn{4}{|l|}{ Average } & \multicolumn{2}{|r|}{ Average } \\
\hline Silvertone & 11 & 11 & 11 & 16 & 12.3 & 11 & 16 & 11 & 11 & 12.3 \\
\hline Halo & 11 & 11 & 16 & 11 & 12.3 & 11 & 11 & 16 & 11 & 12.3 \\
\hline \multirow{4}{*}{$\begin{array}{l}\text { Indianapolis } \\
\text { ka } \\
\text { Average }\end{array}$} & 11 & 13 & 13 & 13 & 12.3 & 11 & 13 & 16 & 13 & 14.3 \\
\hline & & & & & & & & & & \\
\hline & 11.0 & 11.7 & 13.3 & 12.7 & & 11.0 & 13.3 & 14.0 & 12.7 & \\
\hline & \multicolumn{10}{|c|}{$\begin{array}{l}\text { Juurtumis-\% } \\
\text { Rooting-\% }\end{array}$} \\
\hline Silvertone & 100 & 95.2 & 90.5 & 96.3 & 96.3 & 100 & 100 & 100 & 100 & 100.0 \\
\hline Halo & 100 & 100 & 100 & 100 & 100.0 & 100 & 100 & 100 & 100 & 100.0 \\
\hline Indianapolis & 100 & 100 & 100 & 100 & 100.0 & 100 & 100 & 100 & 100 & 100.0 \\
\hline ka & & & & & & & & & & \\
\hline Average & 100.0 & 98.4 & 93.5 & 98.4 & 100.0 & 100.0 & $\begin{aligned} & 100.0 \\
= & 6.5\end{aligned}$ & 100.0 & 100.0 & \\
\hline
\end{tabular}


Juurtumisaika ja juurtumisprosentit esitetään taulukossa 1. Taulukoista puuttuvat vanhan turvehiekka-alustan tulokset, koska juurtuminen tällä alustalla epäonnistui täysin, sillä juuria ei kehittynyt tai ne ruskettuivat heti kasvun alettua. Juurtuminen tapahtui nopeimmin hiekka-alustalla. Käsiteltyjen pistokkaiden juurtuminen oli keskimääräisesti vähän hitaampaa kuin käsittelemättömien. Hidastuminen johtui todennäköisesti pistokasmateriaalin epätasaisuudesta. Käsitellyt pistokkaat juurtuivat kaikissa koejäsenissä sataprosenttisesti. Käsittelemättömistä pistokkaista vain Silvertonen juurtumisprosentti jäi alle sadan multa, vermikuliitti ja turvehiekka-alustalla.

Juurten lukumäärä pistokasta kohden esitetään taulukossa 2. Kuvasta 2 käy selville keskimääräinen juurten lukumäärä eri alustoilla. Lajikkeiden välillä ei, samoin kuin ei alustojenkaan välillä, ole merkitseviä eroja juurten lukumäärissä. Sen sijaan käsittelytapojen väliset erot ovat erittän merkitseviä. Käsittelemättömissä pistokkaissa oli juuria keskimäärin $11 \mathrm{kpl}$ ja hormonikäsitellyissä $18.4 \mathrm{kpl}$. Suurimmaksi ero muodostui vermikuliittialustalla, jolla käsitellyissä pistokkaissa oli $66 \%$ enemmän juuria kuin käsittelemättömissä (kuva 2).

Kuva 2. Krysanteemin pistokkaiden juurrutuskoe. Hyvinkää v. 1960.

Fig 2. Rootind experiment of chrysanthemum cuttings.

Juurten lukumäärä pistokasta kohden keskimäärin eri alustoilla

The average No. of roots per cutting in various rooting media

Juuria $\mathrm{kpl} /$ pistokas

No. of roots/cutting

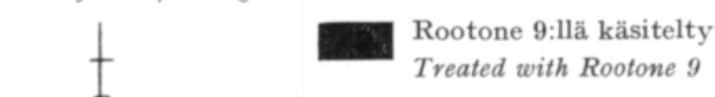

$\mathrm{A}=$ hiekka-alusta, sand

$\mathbf{B}=$ multa, soil

$\mathrm{C}=$ vermikuliittialusta, vermiculite

$\mathrm{D}=$ turvehiekka-alusta, peat + sand 
Juuriston keskimääräinen pituus lajikkeittain eri alustoilla käy selville taulukosta 2. Hormonikäsittelyllä ei ollut merkitsevää vaikutusta juuriston pituuteen. Sen sijaan eri alustojen välillä oli havaittavissa merkitseviä eroja. Multa-alustalla juuristo kehittyi pitemmäksi kuin muilla alustoilla. Samaten turve-hiekka-alustalla juuristo oli verraten pitkä. Kaikkien hormonilla käsiteltyjen pistokkaiden juuret kehittyivät tasaisesti vermikuliittialustalla.

Verson lisäkasvu jatkui juurrutuksen aikana kuten käy ilmi taulukosta 2 . Kasvu oli suurin multa-alustalla ja vähäisin vermikuliittialustalla, joskaan erot eivät ole merkitseviä eri alustojen välillä. Hormonikäsittely ei vaikuttanut sanottavasti verson lisäkasvuun. Eri lajikkeiden lisäkasvussa havaitaan sen sijaan merkitseviä eroja.

Taulukko 2. Krysanteemin pistokkaiden juurrutuskoe. Hyvinkää 1962

Table 2. Rooting experiment of chrysanthemum cuttings.

$$
\begin{array}{cc}
\mathrm{A}=\text { hiekka }_{\text {sand }} & \mathrm{C}=\begin{array}{c}
\text { vermikuliitti } \\
\text { vermiculite }
\end{array} \\
\mathrm{B}=\underset{\text { soil }}{\text { multa }} & \mathrm{D}=\begin{array}{c}
\text { turvehiekka } \\
\text { peat }+ \text { sand }
\end{array}
\end{array}
$$

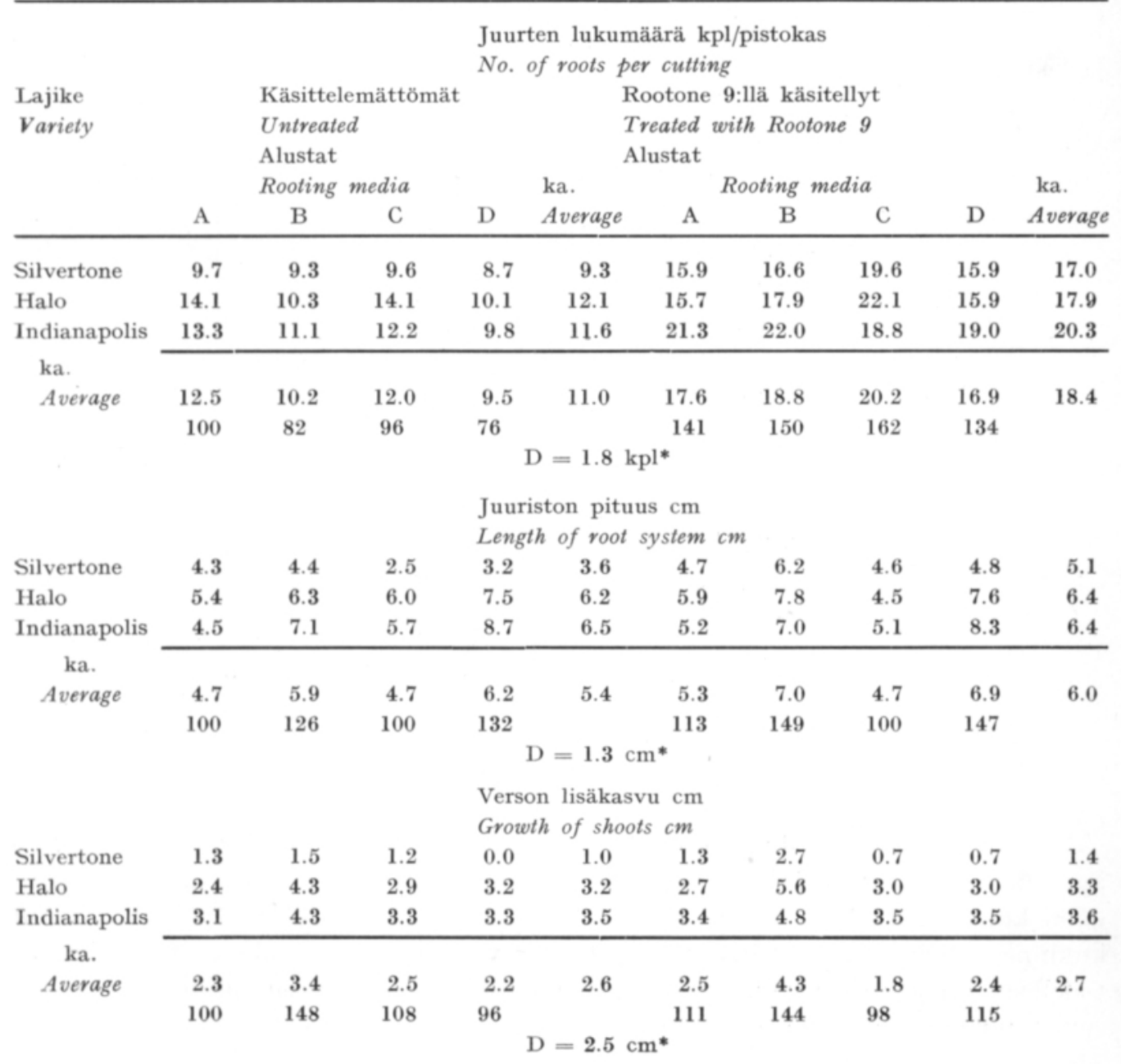




\section{Krysanteemin pistokastaimien koulimiskoe}

Krysanteemin pistokastaimien koulimiskoe suoritettiin Hyvinkäällä K. Vakkurin puutarhassa. Viljely tapahtui uudessa blokkihuoneessa 26.7. - 2. 10. välisenä aikana. Penkkien leveys oli $120 \mathrm{~cm}$, ja multakerroksen vahvuus niissä oli $20 \mathrm{~cm}$. Multa oli savimultaa, johon lisättiin 1 normaali paali turvepehkua penkin jokaista $18 \mathrm{~m}^{2}$ kohti. Lannoitteiden lisäys, samoin kuin kasvuaikana annettu lannoitus, suoritettiin maa-analyysien mukaan. Koulimismultana käytettiin samaa multaa. Pistokkaat juurrutettiin samalla tavoin kuin pistokkaiden juurrutuskokeessa.

Kokeessa verrattiin suoraan istutusta ja kahta koulimistapaa seuraavasti:

1. Istutus suoraan penkkiin kasvupaikalle.

2. Ruukutus $3.5^{\prime \prime}$-ruukkuihin ja istutus penkkiin 2 viikon kuluttua.

3. Koulinta taimilaatikoihin (21 tainta $25 \times 45 \mathrm{~cm}: \mathrm{n}$ laatikkoon) ja istutus penkkiin 2 viikon kuluttua koulimisesta.

Mukana oli kolme lajiketta, Bucksin, Silvertone ja Halo. Kutakin lajiketta istutettiin 21 tainta kolmeen eri kerranteeseen lohkottain satunnaistettujen ruutujen menetelmän $(6,5)$ mukaisesti. Istutustiheys oli koeruuduissa 38.8 tainta/m², ja laskettu sato niin ollen kolmihaaraisena viljeltäessä 116.4 kukkavartta $/ \mathrm{m}^{2}$.

Viljely tapahtui yleisiä lyhytpäiväkrysanteemin viljelysohjeita seuraten. Päivän pituutta lyhennettiin 9 tunniksi 27. 8. - 15. 9. välisenä aikana.

Tulosten tilastollinen tarkastelu suoritettiin samoin kuin pistokkaiden juurrutuskokeessa.

Kokeen tulosta arvioitaessa otettiin huomioon seuraavat seikat:

1. Kasvuaika istutuksesta kukintaan.

2. Versohaarojen pituus lyhytpäiväkäsittelyn alkaessa.

3. Kukkavarsien määrä laatuluokittain.

4. Kukkavarsien pituus.

5. Kukintojen lukumäärä vartta kohden.

Kasvustojen kehittyminen tapahtui nopeasti sitten, kun latvonnan jälkeinen haarottuminen oli päässyt alkuun. Kukinta alkoi eri koejäsenissä tasaisesti.

Kasvuajat istutuksesta kukintaan on esitetty alla olevassa asetelmassa.

\begin{tabular}{|c|c|c|c|}
\hline Lajike & $\begin{array}{l}\text { Kasvuaika vrk } \\
\text { Time from plan. }\end{array}$ & $\begin{array}{l}\text { stutuksesta } \mathrm{k} \\
\text { ing to floweri }\end{array}$ & $\begin{array}{l}\text { ukintaan } \\
\text { ng (days) }\end{array}$ \\
\hline Variety & $\begin{array}{l}\text { Suoraan istutettu } \\
\text { Direct planted }\end{array}$ & $\begin{array}{l}\text { Ruukutettu } \\
\text { Potted }\end{array}$ & $\begin{array}{l}\text { Laatikkoon koulitut } \\
\text { Planted in box }\end{array}$ \\
\hline Buckskin & 86 & 89 & 90 \\
\hline Silverstone & 89 & 91 & 91 \\
\hline Halo & 91 & 94 & 94 \\
\hline
\end{tabular}

Kuten asetelmasta ilmenee, ovat kaikki kolme koelajiketta kehittyneet nopeammin suoraan kasvualustalleen istutettuna kuin koulittuna. Ruukutuksen ja laatikkoon koulimisen välillä ei sen sijaan ole mainittavaa eroa. Lyhytpäiväkäsittelyn kukinnan alkamista tasoittavan vaikutuksen vuoksi eivät asetelman luvut ilmaise todellisia eroja kehitysnopeudessa. Siksi versohaarojen kasvu on mitattu myös ennen pimentämisen aloittamista. 
Taulukko 3. Krysanteemin pistokastaimien koulimiskoe. Hyvinkää 1960

Table 3. Experiment on propagation treatments of chrysanthemum cuttings.

Versohaarojen pituus lyhytpäiväkäsittelyn alkaessa.

Length of shoots in the beginning of short-day treatment.

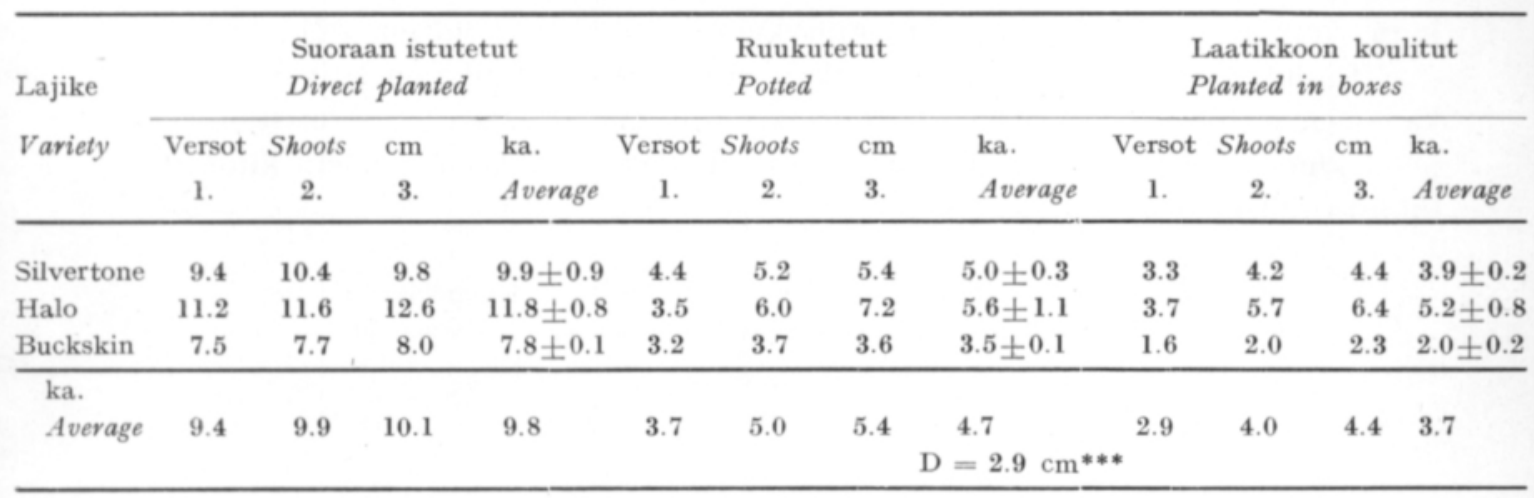

Versohaarojen pituus lyhytpäiväkäsittelyn alkaessa esitetään kunkin kolmen verson osalta erikseen taulukossa 3 . Siitä käy selville, että suoraan kasvupaikan penkkiin istutetut taimet ovat kehittyneet nopeammin kuin koulitut. Erot ovat kaikkien lajikkeieen kohdalla lähes yhtä suuret ja ne ovat merkitseviä. Lisäksi ilmenee, että ylimmän verson kehitys on ollut nopeampaa kuin alempien. Koulittujen taimien kohdalla on ylimmän ja alimman verson välinen ero merkitsevä.

Kukkavarsien määrä esitetään taulukossa 4 laatuluokittain. Luokittelussa seurattiin kaupallisia lajitteluohjeita. Taulukosta 4 havaitaan, etteivät kaikki versot ehtineet kehittää kukkaa eikä kukkavarsien määrä ollut alhaisempi kuin laskettu sato. Satotappio oli suurin laatikkoon koulittujen taimien osalla. Ensimmäisen luokan versoja saatiin kaikista lajikkeista merkitsevästi enemmän suoraan penkkiin istutetuista taimista kuin koulituista.

Taulukko 4. Krysanteemin pistokastaimien koulimiskoe. Hyvinkää 1962.

Table 4. Experiment on propagation treatments of chrysanthemum cuttings.

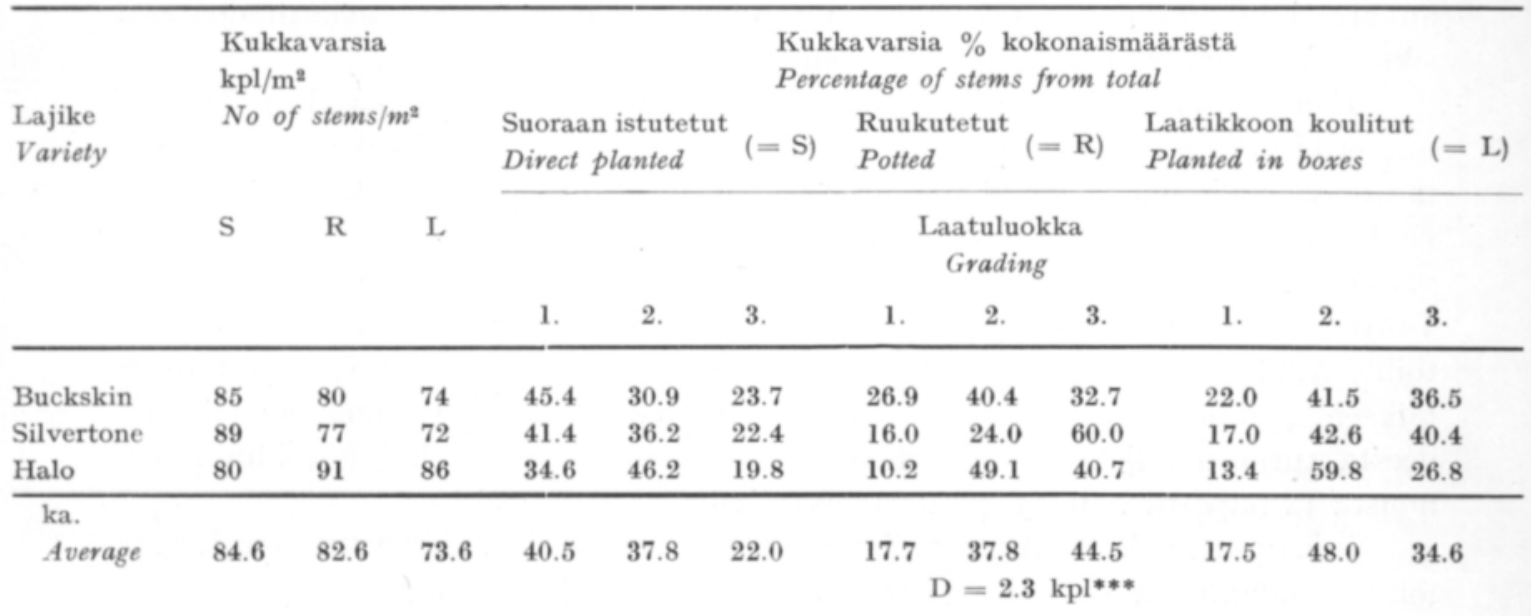


Kukintojen lukumäärä vartta kohden esitetään taulukossa 5. Lajikkeiden välillä ei kukintojen määrässä ole merkitseviä eroja. Sitävastoin koulittujen ja suoraan penkkiin istutettujen välillä erot kukintojen lukumäärissä ovat merkitseviä. Suoraanistutetuissa oli kukintojen määrä kukkavartta kohti $28 \%$ suurempi kuin ruukutetuissa ja $23 \%$ suurempi kuin laatikkoon koulituissa keskimäärin.

Taulukossa 5 esitetään lisäksi kukkavarren pituus. Kaikkien lajikkeiden kukkavarren pituus oli merkitsevästi suurempi penkkiin suoraan istutetuissa koejäsenissä kuin koulituissa. Verson pituus vaihteli lisäksi lajikkeen mukaan kuten taulukosta ilmenee.

Taulukko 5. Krysanteemin pistokkaiden koulimiskoe. Hyvinkää 1960.

Table 5. The experiment in propagation treatments with chrysanthemum cuttings.

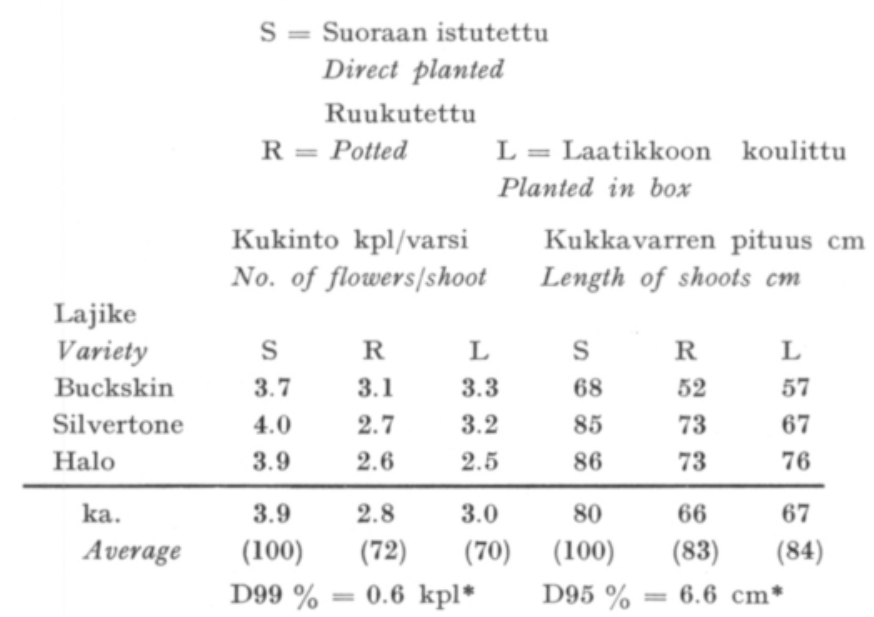

\section{Tulosten tarkastelu}

Krysanteemin pistokkaiden juurruttamiskoe. Kokeen alottamisaikana esiintyi pistokkaiden saannissa tiettyjä vaikeuksia. Lajittelua ei voitu suorittaa riittävän ankarasti ja niin jäivät pistokkaat puutumisasteeltaan jossain määrin epätasaisiksi. Tämä näkyi juurtumisajoissa häiritsevänä epätasaisuutena.

Juurtumisen täydellinen epäonnistuminen vanhalla turvehiekka-alustalla osoittaa, ettei samaa alustaa voida käyttää useampien kuin yhden pistokaserän juurruttamiseen. Suoranaista syytä juurtumisen estymiseen ei tämän kokeen perusteella voida määrittää. Koska juurtuminen estyi kokonaan tai juurten kärjet ruskettuivat heti juuren alettua kasvaa, kyseessä oli ilmeisesti eräänlainen myrkkyvaurio. Tautisaastunnasta voi tuskin olla kysymys, sillä vioitus ei levinnyt viereisille alustoille, vaikka alustat saivat olla paikoillaan jonkin aikaa vielä kokeen lopettamisen jälkeen. Mahdollisesti vioitus aiheutui kasvihuoneolosuhteissa voimakkaana alkaneesta turpeen hajoamisesta, jolloin $\mathrm{pH}$ on voinut laskea, hiilidioksidin määrä nousta ja hapesta esiintyä puutetta (vrt. 16).

Juurtumistulokset eri alustoilla olivat samansuuntaisia niiden tulosten kanssa, joihin johdannossa viitataan $(7,8,11,13,18,19)$. Juuriston muotoon on ilmei- 
sesti syytä kiinnittää entistä enemmän huomiota. Istutuksen suorituksen kannalta näyttää suhteellisen lyhyt, mutta tuuhea juuristo edullisimmilta, sillä se vioittuu vähiten istutuksessa. Tässä suhteessa vermikuliitti ja hiekka olivat kokeessa muita alustoja selvästi parempia.

Hormonikäsittely osoittautui kokeessa selvästi kannattavaksi (taulukko 1 ja piirros 2). Hormonikäsittelyn vaikutus tuli esiin ensisijaisesti juurten lukumäärän lisääntymisessä, kun sen sijaan juuren pituuskasvuun ja verson kehitykseen sillä tuskin oli havaittavaa vaikutusta. Ravinteita sisältävällä multa-alustalla hormonkäsittelyn vaikutus oli prosentuaalisesti edullisin (vrt. 16, 17, 19).

Krysanteemin pistokastaimien koulimiskoe. Latvonnan jälkeen tapahtui koulittujen taimien sivuversojen kasvuunlähtö epätasaisesti. Varsinkin alimmat 1. ja 2. verso kehittyivät muita selvästi hitaammin (taulukko 3). Tämä aiheutui ilmeisestikin siitä, että koulinnan seurauksena taimien kasvu pysähtyi ja tapahtui nopea puutuminen. Tätä tukee myös se, että lähempänä tyveä, jossa puutuminen ensin alkaa, versojen kasvu oli hitainta. Tulos vahvistaa yleistä viljelyohjetta, jossa kielletään latvomasta taimia puutuneeseen versoon saakka, koska haarominen siitä hidastuu.

Versohaarojen pituudella lyjytpäiväkäsittelyä aloitettaessa ei ollut niin selvää vaikutusta sadon laatuun kuten OKADA (12) kokeissaan on havainnut. Voidaan olettaa, että sadon laatu oli koulituissa koejäsenissä huonompaa siitä syystä, että varsohaarat olivat heikommin kehittyneitä kuin suoraan penkkiin istutetuissa koejäsenissä. Korrelaatio ei kuitenkaan ole kokeessa selvä.

Koulimisen suoranaisen vaikutuksen sadon laatuun on katsottava kokeessa olleen selvästi negatiivisen niin ruukutuksen kuin laatikkoon koulimisenkin osalta. Tämä ilmeni kokeessa seuraavista seikoista:

Versohaarojen kehittyminen ennen lyhytpäiväkäsittelyä oli nopeampaa ja tasaisempaa suoraan penkkiin istutetuissa taimissa kuin koulituissa (vrt. taulukko 3).

Koulimattomista taimista 1. luokan kukkavarsia merkitsevästi enemmän kuin koulituista (taulukko 4).

Suoraan kasvupaikalleen istutettujen kukintojen määrä kukkavartta kohden oli selvästi suurempi kuin koulituissa taimissa (vrt. taulukko 6).

Lisäksi kukinta alkoi jonkin verran aikaisemmin ja kukkavarret olivat voimakkaammin kehittyneitä koulimattomissa koejäsenissä kuin koulituissa (taulukko 5 ja asetelma s. 204).

Näiden tulosten perusteella on krysanteemia pidettävä kasvina, joka reagoi herkästi koulimisen aiheuttamaan juuriston vioituksiin. Sen kasvu pysähtyy, mikä puolestaan lyhytpäiväkrysanteemin viljelyssä ilmenee sadon laadun heikkenemisenä (vrt. 1. ja 3.). On todennäköistä, että luonnollisen kasvurytmin mukaan krysanteemejä viljeltäessä pitkä kasvuaika tasoittaa useista ruukutuksista aiheutuvat kasvun pysähtymiset siinä määrin, että krysanteemin on katsottu suosivan koulimista. 
Vahvin ja muodoltaan paras juuristo kehittyi krysanteemin pistokkaisiin vermikuliitti- ja hiekka-alustoilla.

Rootone 9:llä käsittelyn ansiosta muodostui krysanteemin pistokkaisiin erittäin vahva ja hyvämuotoinen juuristo sekä juurtuminen varmentui.

Versohaaran pituudella lyhytpäiväkäsittelyä aloitettaessa ei ollut ratkaisevaa merkitystä kukinnan onnistumiseen. On kuitenkin ilmeistä, että voimakkaasti alkuun lähteneet versot antavat paremman sadon kuin hennot ja hitaasti alkuun päässeet.

Kasvuston kehitys oli nopeinta ja laadullisesti paras sato saatiin silloin, kun lyhytpäiväkrysanteemin taimet istutettiin suoraan kasvupaikalleen. Näin ollen on pistokkaiden käsittely niiden juurruttua pyrittävä supistamaan yhteen uudelleen istutuskertaan, sillä juuristo vioittuu herkästi, mistä taas on seurauksena kasvun hidastuminen ja sadon laadun heikkeneminen.

\section{K I R J A L L I S U U T T A}

(1) Allerton, F. W. 1960. Direct-planted chrysanthemums. Comm. Gr. 3350: 705-707.

(2) Avery, G. S., Johnson, E. B. et al. 1947. Hormones and horticulture. 362 p. New York.

(3) Ball, J. 1955. The Ball mum guide. 89 p. Chicago.

(4) Gathey, H. M. 1955. Temperature guide to chrysanthemum varieties. New York State Flower Growers 119: 1-4.

(5) Finney, D. J. 1953. An indroduction to statistical science in agriculture. $179 \mathrm{p}$. Copenhagen.

(6) Goulden, G. H. 1956. Methods of statistical analysis. 467 p. New York.

(7) Hermans, J. 1960. Modern chrysanthemumodling. Trädgårdsnytt 14, 2: 19-21.

(8) Hudson, J. P. 1956. Recent advances in plant propagation. Agricul. Rev. 1, 11:38-41.

(9) Kains, M. G. \& McQhesten, L. M. 1948. Propagation of plants. 639 p. New York.

(10) Kristoffersen, T. 1957. Krysanthemum (Chrysanthemum $x$ hortorum BaILeY) som kortdagsplante. Gartneryrket 47: 807-827.

(11) Mattila, S. 1956. Tilastotiede 1. $115 \mathrm{~s}$. Moniste.

(12) ОкарA, M. 1952. On the relation of stem length, leaf area to flower bud formation in chrysanthemums. J. Hort. Ass. Japan 21: 174.

(13) Post, K. 1949. Florist crop production and marketing. 891 p. New York.

(14) QuARRell, C. P. \& CoOKe, D. 1957. Effect of propagation treatments on cropping of chrysanthemums. Exp. Hort. 1: $5-7$.

(15) RIEHL, G. 1956. Der Einfluss verschiedener Umweltbedingungen in der Gärtnerischen Stecklingsvermehrung bei Unterbewässerung. Arch. Gartenb., 1956. 4: 433-522.

(16) - - 1957. Der Einfluss der Blattfläche auf die Stecklingsbewurzelung. Deut. Gartenb., 4. $65-67$.

(17) RUPPRECHT, H. 1958. Ein Beitrag zur Wuchsstoffanwendung bei der Stechlingsvermehrung bei Unterbewässerung. Arch. Gartenb., 4, 5: 413-427.

(18) Searle, S. A. \& Machin, B. J. 1957. Chrysanthemum the year round. 273 p. London.

(19) Stoutemyer, V. T. 1954. Apparatus and materials. The national horticultural magazine. 33, 1: $48-53$.

(20) Thistlewaite, E. T. 1960. Chrysanthemums. 168 p. Norwich.

(21) ThorSRud, А. 1953. Kukkien viljely lasin alla. 442 s. Porvoo. 
S U M M A R Y :

\title{
TRIALS WITH ROOTING AND PROPAGATION TREATMENTS OF SHORT DAY CHRYSANTHEMUMS
}

\author{
Erkki Kaukovirta
}

University of Helsinki, Department of Horticulture

The experiments carried out at K. Vakkuri's nurseries at Hyvinkää in accordance with the research programme of the Horticultural Department of the University of Helsinki were designed to study 1) the influence of rooting media and hormone treatment on the rooting of chrysanthemum cuttings in circumstances in which automatic watering cannot be provided, and 2) the effect of propagation treatment of cuttings on the quality of the crop.

In the rooting experiments sand, soil, vermiculite, peat and sand, as well as previously used peat and sand media were used. Tested varities, Silvertone, Halo and Indianapolis, yielded the best results on sand and vermiculite media, which produced a thick rooting system in the cuttings (Tables 1 and 2). In these media the roots furthermore developed a shape suitable for replanting (Fig. 1). Hormone treatment increased significantly the number of the roots (Table 2), but had hardly any effect on the length of the roots or stem. In the used peat sand rooting media the cuttings either developed no roots at all, or, if roots started growing, they turned brown at once. This was probably due to the poisonous effect of the decaying products in the peat.

In the propagation treatment experiment on cuttings the quality of the crops yielded by potted cuttings and those planted in boxes was compared directly with that of cuttings planted directly into their flowering quarters. Each cutting was grown with three stems. Three varieties, Silvertone, Halo and Buckskin, were used in the experiment. It was found that both the propagation treatments, potting and planting in boxes, clearly lowered the quality of the crop (Tables $3,4,5)$. The shoots of these cuttings showed a slower rate of growth after pinching, and furthermore, they produced significantly smaller quantities of first class flowering stems, there were fewer blooms per stem and the flowering began later than in cuttings planted directly into their flowering quarters. 